\title{
VERTICAL PATTERNATOR FOR EVALUATION OF THE HYDRAULIC SPRAYERS
}

\author{
Sehsah, E.M.*
}

\section{ABSTRACT}

In Egypt, it could be not able to test the vertical distribution for agriculture sprayer machines this may be due to the poor measuring instruments such as vertical patternator. The aim of the current research is develop and evaluate an inexpensive vertical patternator for hydraulic sprayers. The study carried out in laboratory of agricultural engineering dept., faculty of agriculture, kafr El-Sheikh University. The vertical patternator manufactured from the local material under laboratory and work station in kafr El Sheikh University. The tests and the evaluation of the patternator included two main parameters. The first treatment was evaluation the three vertical sprayers under laboratory conditions. As well as, the second treatment was evaluation two different measured methods to determine the efficiency of the sprayer by using the CV\%. The results indicated that, the Tee-jet XR 110-3 VP nozzles gave the highest percentage value of spray liquid captured compared to Hardi110-02 LS and LU110-04 nozzles. The development patternator captured more spray liquid due to increase of the operating pressure of spray liquid. The t-test value for LU 110-04 nozzle was -1.48 with standard error (SE) 0.23 and probability P-value 0.89. It could be used the automatic method to estimate the $C V \%$ and it's easy to apply. As well as, there are no different effect between manual and automatic method at the volume application rate $200 \mathrm{l} / f a d d ., 400 \mathrm{l} / f a d d$. and $500 \mathrm{l} /$ fadd for the $\mathrm{CV} \%$.

Keywords: Spray distribution, Patternator.

\section{INTRODUCTION}

7 he use of patternator relates principally to achieving a uniform volume distribution pattern at a horizontal surface, and therefore 1 may only be relevant for flat fan hydraulic pressure nozzles designed to achieve this. Vertical and horizontal movements of boom sprayers represent one of the elements affecting the quality of pesticide distribution and the effectiveness of the treatments.

* Associate Prof., of Dept. Agric. Eng. Dept Fac., of Agriculture, Kafr El-Sheikh Univ. 33516- kafr el sheikh, Egypt sehsah_2000@yahoo.de 
Vertical movements produce variations of the height of the nozzles, determining, as a consequence, areas over-sprayed by contiguous nozzles and areas under-sprayed or unsprayed: in any case the quantity of product distributed at ground differs from the optimum value. The assumption that biological efficacy, particularly for foliar and insect targets, can be predicted by patternator measurements made in a static laboratory situation is highly questionable Sehsah, and Kleisinger (2007): Measurements of spray distribution by a patternator do not relate directly to deposition on the actual biological target which will vary greatly with the application. The actual biological target area ranges from the soil to the ear or stem of a cereal plant with insects, fungi and weeds presenting vastly differing type of target. Also the target area for deposition against a particular pest can vary even with the particular chemical used depending on its mode of action. For example, to optimally control an insect living on an under-leaf surface, contact, systemic and vapour acting chemicals would need to be applied to different specific target areas for maximum efficiency. Different nozzles have been shown to give different types of overall deposit pattern. Webb et al (2002) have shown that the deposit ratio between horizontal and vertical targets differs significantly between flat fan and air induction nozzles. It has long been known that air assisted sprayers also change these deposit ratios and the effect will vary differently with different dynamic factors Ringel et al (1991), Nordbo and Taylor (1991), Nordbo (1992). Thus a simple two-dimensional measurement of the horizontal deposition profile may well be very misleading regarding predicting deposition on (complex) threedimensional targets. Lund and Jensen, (2002) specifically suggests that biological efficacy of various nozzles used for band spraying was not related to the measured horizontal spray distribution pattern. Krishnan et al. (2005) studied the effects of spray boom deflection, wind velocity, and wind direction on spray pattern displacement (SPD) of extended range of 110-0 fan nozzles by using patternator. Tests were conducted at four nozzle pressures of 139, 208, 313 and $383 \mathrm{kPa}$. At each pressure, tests were conducted at four winds conditions and including combinations of both cross and head wind However, coefficient of variation (C.V., \%) values of $8.5 \%$ to $13.5 \%$ obtained from these tests indicated uniform or 
acceptable coverage. Sehsah, (2007):, and Sehsah and Kleisinger (2009) indicated that the spray distribution is improved by increasing nozzle size, pressure and reduces the nozzle height. The type of nozzles is very important parameters which affect the distribution of pattern (C.V. \%). Herbst and Wolf (2001), and Richardson et. al., (2000) indicated that the selection of nozzles may be reduced the losses of spray dose and gives good distribution of pattern. Static indoor patternator measurements ignore the dynamic effects of boom and air movement on spray distribution with air movements and micro-climatic conditions greatly influencing deposition patterns (particularly with more biologically efficient smaller droplets where turbulent transport is often a very significant factor in spray distribution and deposition). Koch (1992) clearly demonstrated that spray distribution on stationary patternator had limited correlation with uniformity of spray deposits on natural targets in the field. The European SPECS project, and other work, shows that coefficients of variation of $7 \%$ to $9 \%$ achieved on a static patternator under laboratory conditions can translate to values of over $30 \%$ under field conditions Sinfort and Herbst (1996), Richards et al (1997). Balsari et al (1994) also studied the issue and showed CV was not the most critical issue affecting the biological efficacy of herbicide treatments. Koch and Weisser (1996) clearly demonstrated the importance of dynamic factors and states: 'Spray distribution, measured under static conditions on a patternator, does not represent the pattern achieved in routine dynamic applications. Each specific sprayer configuration defined by nozzle type, spraying height, pressure and speed yields in a specific horizontal dynamic distribution pattern which is unpredictable and shows longitudinal strips of distinct deposit levels on targets within the sprayed area. A number of factors affect the deposition and retention of pesticide on the plants. The examples of such factors are canopy structure of the target crop, spray application factors and properties of the sprayed liquid and air-assistance to hydraulic boom of the sprayers. Leaf morphological features such as shape, leaf orientation and leaf age may also affect retention. A part of the spray can be lost during the application before the droplets are deposited on plants or soil. Droplets can be transported out of the sprayed field by spray drift. 


\section{OBJECTIVES}

The main objectives are developed and evaluated of an inexpensive vertical patternator that researchers or growers can construct at their farm workshop under Egyptian conditions. As well as, increase the efficiency of application by improving the technical condition of sprayers. Reduce pesticide application costs for growers by correct targeting. Also, decrease environmental pollution.

\section{MATERIALS AND METHODS}

\section{The vertical patternator}

The developed vertical patternator was constructed and manufactured in the laboratory of agricultural engineering department, faculty of agriculture, Kafr El-Sheikh University. Nine $35 \mathrm{~cm}$ x $100 \mathrm{~cm}$ wide fly screens were connected via hooks to two $35 \mathrm{~cm}$ high, $3 \times 1.5 \mathrm{~cm}$ aluminum U-section. A small gutter was attached, at an angle, to the bottom edge of each screen. The gutter sloped to one end where a plastic hose was connected which ran down to a box containing through the flexible polyethylene $10 \mathrm{~mm}$ tube diameter to the $700 \mathrm{~mm}$ length and 80 $\mathrm{mm}$ diameter cylinders. The frame was constructed in two halves for ease of assembly. The collecting cylinders fixed in aluminum frame and the polyethylene $10 \mathrm{~mm}$ tubes were fixed at the top of the collecting cylinders. As well as, the mechanical valve was fixed in the bottom of each collecting cylinders. The mobile unit which driven by the driver pulley that mounted with the stepper motor. The stepper motor was data logger was constructed upon the top of collecting cylinders. As well as, it was moved upon the top of center of the collecting cylinders. The Kimo software program was used to control of the steps for mobile unit. LASER distance instrument was used and fixed in vertical position on the mobile unit to measure the height of the collecting liquid sprayed as shown in figures 1 and 2.

\section{Miscellaneous Transmission Systems}

The belt drive is effective in applications where a small payload is moved at high linear velocities with a high acceleration rate over a relatively short distance with a relatively low accuracy. The linear velocity for the $\mathrm{x}$-axis is calculated with Equation (1) based on the number of collecting cylinders to be inspected (n), cylinder diameter (D), distance between the 
cylinders (d), and inspection time (t). A cylinder diameter of $80 \mathrm{~mm}$ was specified in the patternator system design constraints.

$v=\frac{n \cdot(D+d-1)}{t}$

The angular velocity for the pointing mechanism must be proportional to the velocity and acceleration of the $\mathrm{x}$, axis since the Laser may be cropped if the linear velocity of the $\mathrm{x}$ axis is faster than the rotational velocity of the pointing mechanism. From equation 1, the linear velocities were $2.25 \mathrm{~m} \mathrm{~s}^{-1}, 1.5 \mathrm{~m} \mathrm{~s}^{-1}$ and $1.15 \mathrm{~m} \mathrm{~s}^{-1}$ at operating time $60 \mathrm{~s}, 90 \mathrm{~s}$ and $120 \mathrm{~s}$ respectively. The optimum linear velocity was $1.5 \mathrm{~m} \mathrm{~s}^{-1}$ which gave a good number of operating pulses. The number of operating pulses is expressed as the number of pulse signals that adds up to the angle that the motor must move to get the work from the top first cylinder to last cylinder in the development vertical Patternator. The motor speed limitations may occur due to setting of Kimo software program.

\section{Ultrasonic sensor}

The measured distance range for the above mentioned Atrium Ultrasonic sensor is $40 \mathrm{~mm}$ to $27000 \mathrm{~mm}$. To simplify the sensor procedure, the sensor could be advantageous in a variety of applications, including distance measuring in tight spaces and liquid level control for tubs in patternator.

\section{Spray liquid measurement level setup}

The Atrium Ultrasonic sensor was mounted on the belt which driven by steeper motor. The electric steeper motor was moved from the end of the lift side to the right side in the patternator. In addition, the eclectic motor controlled by the Kimo software program and it was programmed to move over every tube in the patternator as shown in figure 1 . The Laser sensor was moved over the top of every tube in the patternator and measured the distance that indicated the spray liquid levels for each tube. These distances of the spray levels for each tube recorded to calculate the spray volume for each tube, flow rate, and coefficient of variation CV \%. The Voltcraft DL-120th data logger was used to measure the relative humidity and the temperature. As well as the flow-rate and coefficient of variation percentages ( $\mathrm{CV} \%)$ were determined. By computer analysis, from the levels recorded in the patternator tubes for the single candidate 
nozzle, calculate the distribution for a 1.8 meter width (i.e. 9 columns) excluding the ends where there is no overlap. The manometer pressure was monitored using a $0-1500 \mathrm{kPa}$, class $3 \mathrm{~A}$ pressure gauge.

\section{Procedures}

The current research investigates to evaluate the distribution for the development vertical patternator. The vertical patternator comprises a vertical mast which travels through the spray cloud. Droplets are intercepted by a collection device, the resultant liquid then passes through pipes to graduated collection tubes.

1- Vertical collectors 2-Polyethỵlen tubes $10 \mathrm{~mm}$ dia.

3-PVC 3 inch dia. tubes + LASER instrument connected with small car

5-Pulleys

7- Valves

9. $\mathrm{PC}$

\section{6-Stepper motor}

8- Data logger

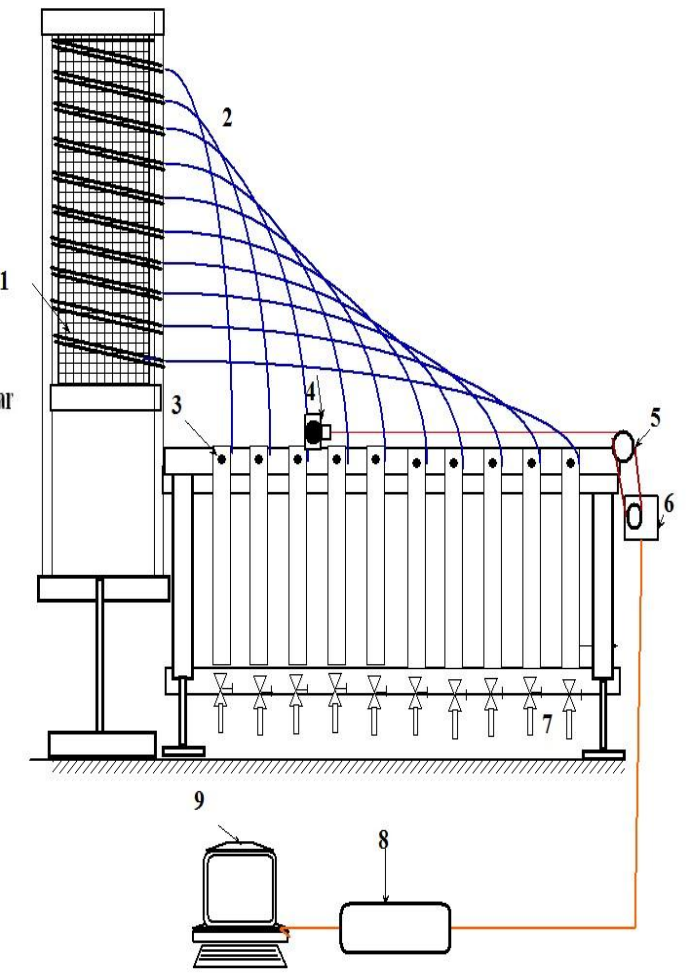

Figure 1: Diagram of developed vertical patternator to measure the vertical uniformity for hydraulic sprayers.

The collected liquid shows a pattern, it shows how the spray is distributed within the tree, and how much spray goes over the top of the canopy as drift. The sprayer operator can adjust nozzle orientation to improve deposition on the target e.g to the fruit zone rather than wasting spray over the canopy. The spray cloud hit the fly screen, the air passing through and the liquid ran down the front of the screen, into the gutter and 
then, via the plastic hose into the collecting PVC cylinders. The duration of spraying experiments are controlled for each treatment operated at 180 second. Operating spray pressures of $125 \mathrm{kPa}, 175 \mathrm{kPa}$ and $250 \mathrm{kPa}$ are applied for three vertical nozzle sprayers to obtain 200 1/fadd., 400 1/fadd. and 500 1/fadd application volume rate. The control unit for liquid pressure and flow-rate adjusted before the vertical nozzle used to obtain the operating pressure nozzles for every treatment. All measurements were made spraying water at a temperature of approximately $24^{\circ} \mathrm{C}$. Environmental conditions were kept constant at a temperature of $24^{\circ} \mathrm{C}$ and a relative humidity between 74 and $86 \%$ as shown in figure 3 . A series of experiments were conducted to test the development patternator with manual and automatic measured to see if the new designs would be as accurate as the "standard" manual measured method. The vertical boom sprayer with three different nozzles were tested, Hardi 110-02 LS, Tee jet XR 110-3 VP nozzles and Lechler LU110-04. The above vertical boom sprayer with three different nozzles were simulated as an air ballast sprayer. All sprayers were equipped to spray the above volume rate and three repetitions were carried out for each trial. As well as there are not found any standard vertical patternator under Egyptian conditions to use in the current research. The main treatment was the two different type methods to measure the vertical spray distribution for three different nozzles. Arrangement and statistical analysis of the experiments was according to randomized design.

\section{Coefficients of Variation (CV, \%)}

The Excel software program was used and with VB programming programmed the coefficient of variation. The coefficients of variation as the percentage of spray pattern for all nozzles treatment were programmed by using the standard equation and excluding the ends where there is no overlap. The data for every treatment were collected for every treatment conditions. The values of spray volume in every cylinder were used to re-calculate the coefficients of variation percentage. The CV \% values were recalculated by using the equations 2,3 , and 4 as follows to obtain a good accuracy for the CV \% (Sehsah and kleisinger, 2009).

$$
X^{\prime}=\frac{\sum X_{i}}{n} \ldots . .(2), \quad s=\sqrt{\frac{\sum\left(x_{i}-x^{\prime}\right)^{2}}{n-1}} \ldots . .(3) \text { and } \quad C V=\frac{s}{x^{\prime}} * 100 \ldots . .(4)
$$


Where C.V. is the coefficients of variation percentage, \%, $\mathrm{xi}$ is the height of liquid in the tube, $\mathrm{cm}$ and, $\mathrm{n}$ is the number of patternator columns.

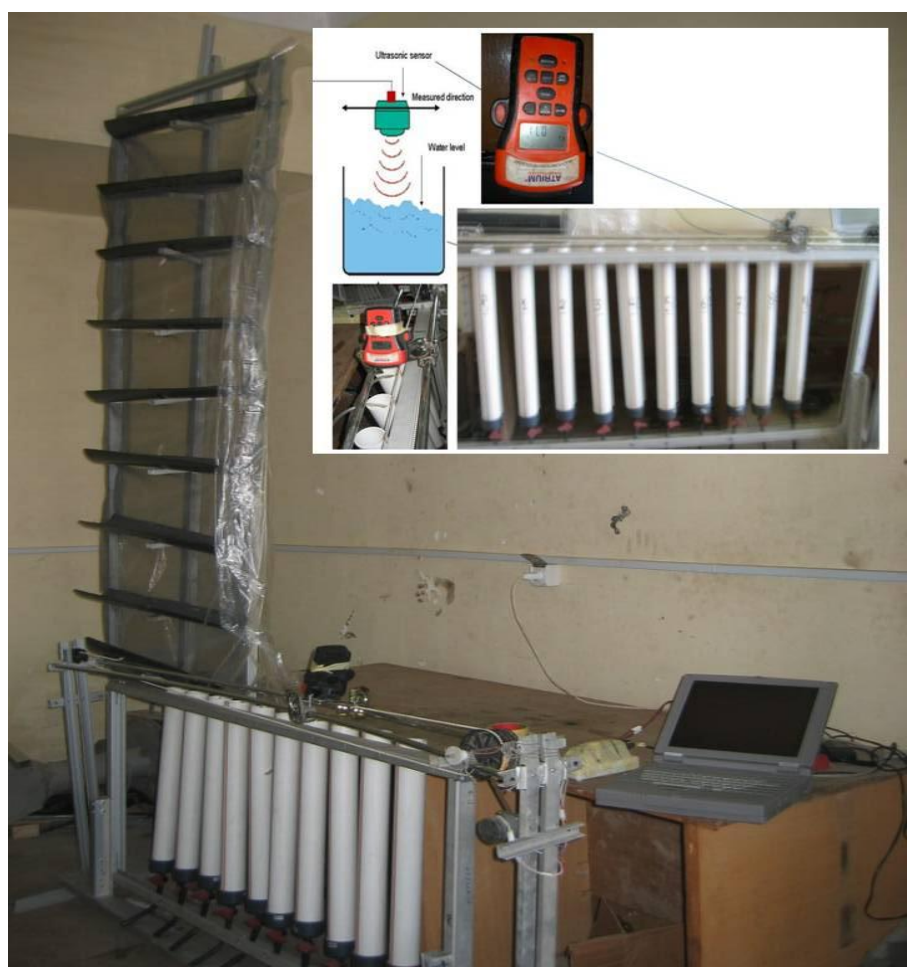

Figure 2: Developmed vertical patternator to measure the vertical uniformity for hydraulic sprayers.

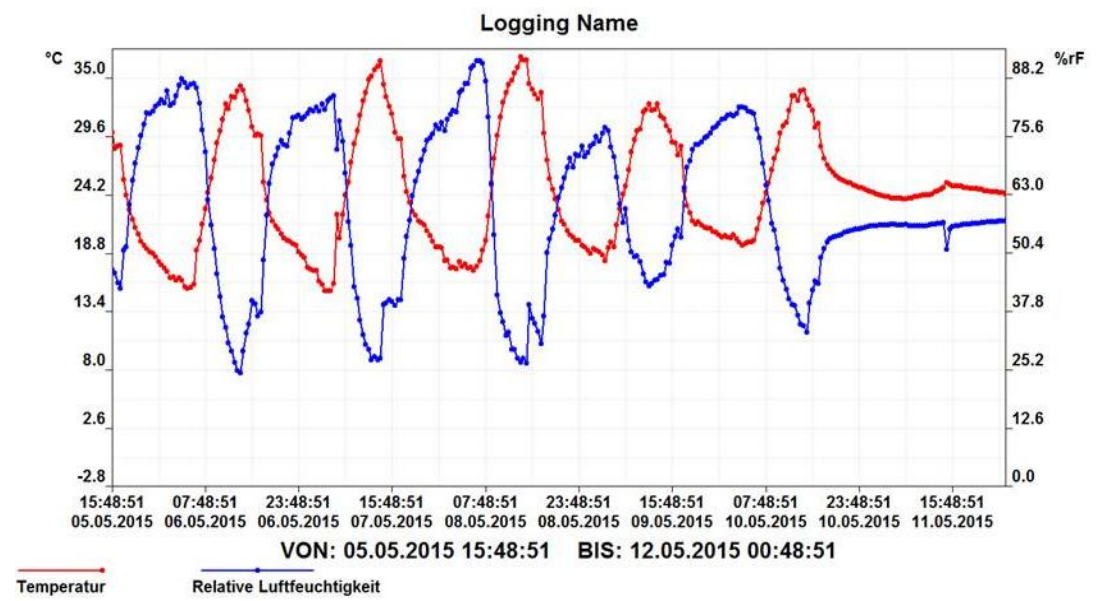

Figure: Measured values of laboratory temperature and relative humidity 


\section{RESULTS AND DISCUSSIONS}

An experiment was conducted to measure the amount recovered by each of the patternator compared to the output of each of the sprayers. Figure 4 and Table 1 shows that the development patternator captured the most, averaging $83.25 \%$ of the applied spray. The highest amount recovered was with the Tee-jet XR 110-3 VP nozzles sprayer when $88.3 \%$ was recovered. Table 1 presented the percentage of spray captured volume for different nozzles at three operating pressure. It is noticed that, the Tee-jet XR 110-3 VP nozzles gave the highest percentage value of spray liquid captured compared to Hardi110-02 LS and LU110-04 nozzles. Figure 4 indicated the collected volume for different operating pressure $125 \mathrm{kPa}$, $175 \mathrm{kPa}$ and $250 \mathrm{kPa}$. It is clearly that, the development patternator captured more spray liquid due to increase of the operating pressure of spray liquid as shown in table 1 .

\section{Coefficient of variation percentage $(\mathrm{CV}, \%)$}

To compare between manual and automatic measured methods for $\mathrm{CV}$ percentage, table 2 indicates that the coefficient of variation percent $\mathrm{CV}$ $\%$ values for different two measured methods in the patternator. It is found that there are no significant different between the automatic and manual measured methods for coefficient of variation percentage. The Origin program version 7 was used to analysis the data. The t-test was used to compare between two measured values of $\mathrm{CV} \%$. The t-test indicated that no significant different between two methods for all treatment condition. The t-test value for LU 110-04 nozzle was -1.48 with standard error (SE) 0.23 and probability P-value 0.89 . The mean values of CV \% for LU110-04 were $12.7 \%$ and $13.7 \%$ at manual and automatic measured respectively. As well as the mean values of CV\% for XR nozzle were $13.6 \%$ and $14.3 \%$ at manual and automatic method respectively. The SE value and P-value for XR nozzle were 0.76 and 0.824 respectively. Also, the mean values of $\mathrm{CV} \%$ for Hardi nozzle were 15.3 $\%$ and $15.7 \%$ at manual and automatic method respectively. The above result indicated that, it may able to use the automatic method to estimate the $\mathrm{CV} \%$ and it's easy to apply. In addition to, the duration time to measure the values in automatic method by using the LASER sensor may be taking a few seconds compared to the manual measured method. 

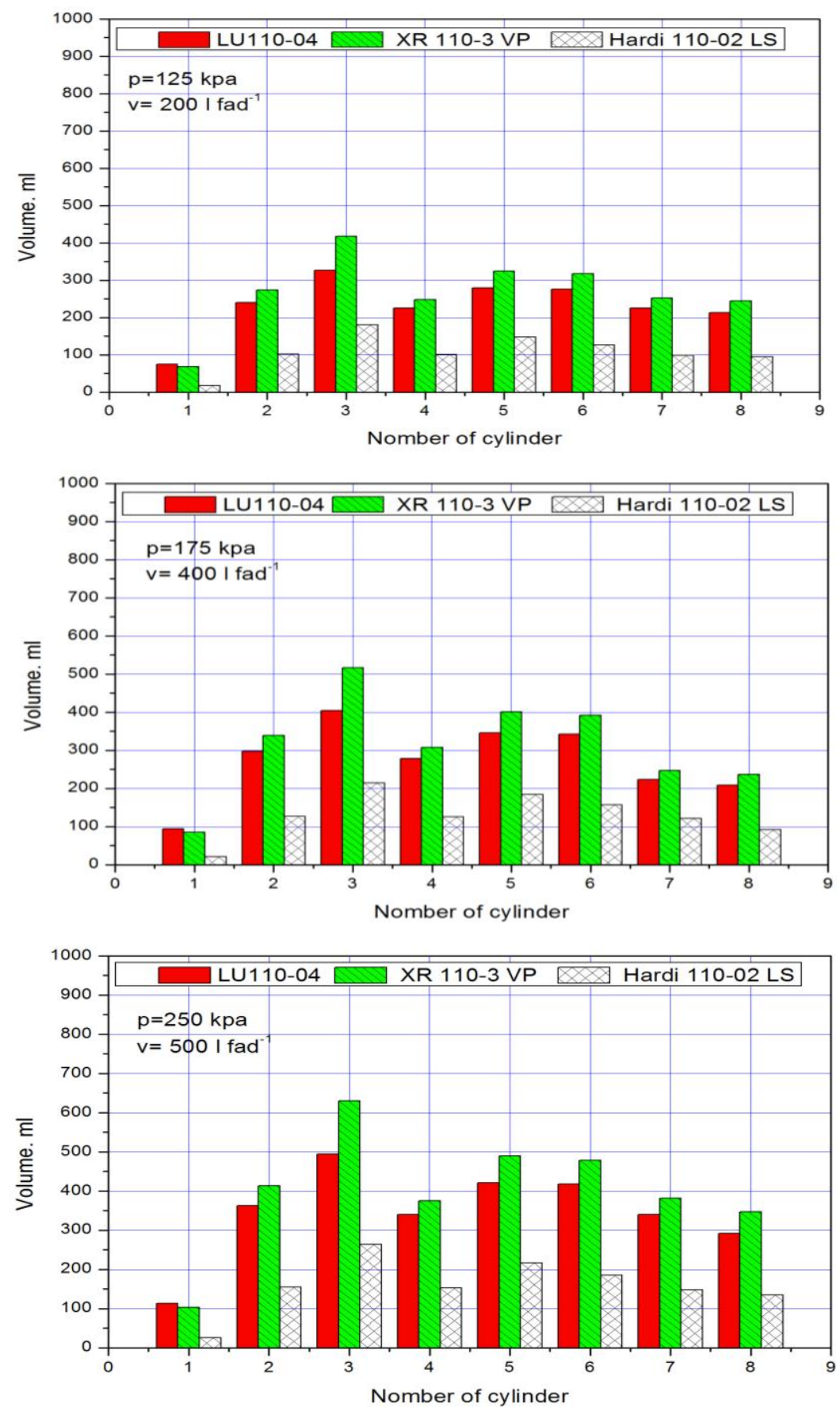

Figure 4: Display the spray volume collected by development patternator under different volume rate and operating pressure. 
Figure 5 indicated that the $\mathrm{CV}$ percent for different nozzles by using development patternator at different volume rate. It is clearly that the increasing of volume application rate tends to increase the $\mathrm{CV} \%$ for all nozzles. As well as, it found that there no different effect between manual and automatic method under three volume application rate 200 1/fadd., 400 1/fadd. and 500 1/fadd.

Table 1: The percentage volumes captured in the development patternator at three different operating pressure for different spray type of nozzles

\begin{tabular}{|l|c|c|c|}
\hline \multicolumn{1}{|c|}{ Nozzles } & $\begin{array}{c}\text { Pressure, } \\
\mathrm{kPa}\end{array}$ & $\begin{array}{c}\text { Flow rate, } \\
1 \mathrm{~min}^{-1}\end{array}$ & $\begin{array}{c}\text { Volume captured } \\
\%\end{array}$ \\
\hline Hardi110-02 LS & 125 & 0.39 & 75.6 \\
\hline Tee-jet XR 110-3 VP & & 1.06 & 83.4 \\
\hline Lechler LU110-04 & & 0.79 & 81.3 \\
\hline Hardi110-02 LS & 175 & 0.44 & 83.0 \\
\hline Tee-jet XR 110-3 VP & & 1.14 & 84.1 \\
\hline Lechler LU110-04 & & 0.91 & 83.2 \\
\hline Hardi110-02 LS & 275 & 0.59 & 82.3 \\
\hline Tee-jet XR 110-3 VP & & 1.45 & 88.3 \\
\hline Lechler LU110-04 & & 1.36 & 84.6 \\
\hline
\end{tabular}

Table 2: Statistical analysis of two different measured methods for coefficient of variation percent $\mathrm{CV} \%$ values in the patternator

\begin{tabular}{|l|c|c|c|c|c|c|}
\hline Nozzles & Mean & SD & SE & t-test & P-value & significant \\
\hline LU-manual & 12.76 & 1.01 & 0.58 & -1.48 & 0.894 & Non \\
\hline LU-automatic & 13.70 & 0.40 & 0.23 & 0.92 & 0.769 & Non \\
\hline XR-manual & 13.63 & 1.40 & 0.81 & -1.24 & 0.723 & Non \\
\hline XR-automatic & 14.30 & 1.32 & 0.76 & 0.79 & 0.824 & Non \\
\hline Hardi-manual & 15.30 & 1.90 & 1.10 & -1.67 & 0.889 & Non \\
\hline Hardi-autmatic & 15.73 & 2.02 & 1.16 & 1.12 & 0.966 & Non \\
\hline
\end{tabular}


Table 3: The coefficient of variation CV \% values for different nozzles at two different measured methods and three application volume rate

\begin{tabular}{|l|c|c|c|c|}
\hline Measuring method & $\begin{array}{c}\text { Application } \\
\text { volume, } \\
\text { 1/fadd }\end{array}$ & $\begin{array}{c}\text { Lechler } \\
\text { LU110- } \\
04\end{array}$ & $\begin{array}{c}\text { Tee-jet } \\
\text { XR 110-3 } \\
\text { VP }\end{array}$ & $\begin{array}{c}\text { Hardi110- } \\
\text { 02 LS }\end{array}$ \\
\hline Manual & 200 & 15.5 & 13.0 & 12.0 \\
\hline Automatic & & 15.9 & 13.3 & 13.3 \\
\hline Manual & 400 & 17.1 & 15.5 & 13.4 \\
\hline Automatic & & 17.4 & 15.8 & 14.1 \\
\hline Manual & 500 & 15.3 & 13.1 & 12.3 \\
\hline Automatic & & 15.9 & 13.8 & 13.7 \\
\hline
\end{tabular}

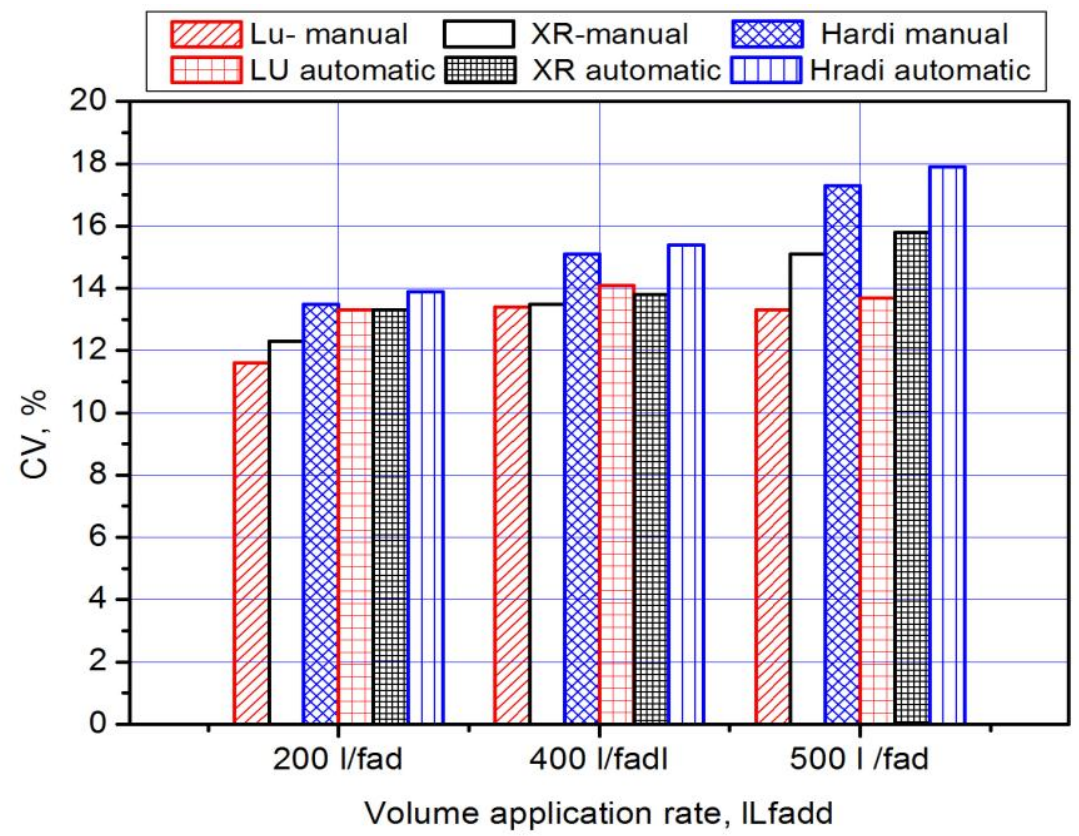

Figure 5: Indicate the $\mathrm{CV}$ percent for different nozzles by using development patternator at different volume rate. 


\section{SUMMARY AND CONCLUSIONS}

The result indicated that the development patternator captured more spray liquid due to increase of the operating pressure of spray liquid. After checking both sets of calibration values, it was concluded that the calibrations were performed according to the guidelines issued by the manufacturers of both measuring devices. It is clearly that the influence of different two measured methods of CV \% is rather small. This applies for both measuring systems. Although these preliminary tests did produce sufficient results to make some well grounded conclusions. It may be able to put forward some tendencies: (1) both manual and automatic system are capable of producing stable spray distribution of the pattern and this for each tested nozzle type and size and (2) the apparatus based on operating pressure is more sensitive of the measuring device. The development patternator may be able to manufacture and use under Egyptian conditions. It will be able to build the own patternator and adjust the sprayers for specific blocks on the farms under local conditions. As well as it will be able to reduce pesticide drift. Also, apply pesticides more effectively leading to better control of insects/diseases as more spray is hitting the target.

\section{REFERENCES}

Balsari, P., G. Airoldi and M. Tamagnone (1994): 'Boom sprayer transverse distribution uniformity (as CV) and treatment effectiveness: first results'. AgEng 1994.

Herbst, A. and P. Wolf (2001): 'Spray deposit distribution from agricultural boom sprayers in dynamic conditions.' ASAE Meeting Paper $01-1054$.

Koch, H. (1992): 'Uber die Bedeutung von geratetechnisch determinierten and stochastisch ablaufenden Prozessen des Applikationsvorgangs für Dosierung und Veritelung von Pflanzenschuzmitteln.' Gesunde Pflanzen, 44. pp 350 - 360.

Lund, I. and P K Jensen (2002): 'Application technology for band spraying: Correlation between liquid band distribution and biological efficacy.' Aspects of Applied Biology, 66. pp 107 - 114. 
Nordbo, E (1992): 'Effects of nozzle size, travel speed and air assistance on deposition on artificial vertical and horizontal targets in laboratory experiments.' Crop Protection, 11. pp $272-278$.

Nordbo, E. and W. A. Taylor, (1991): 'The effect of air assistance and spray quality (drop size) on the availability, uniformity and deposition of spray on contrasting targets.' BCPC Mono 46. pp 113 -124 .

Richards, M. D., E C Hislo and N. M. Western (1997): 'Static and dynamic patternation of hydraulic pressure nozzles.' Aspects of Applied Biology, 48. pp 201 - 208. Richardson, R G; Combellack, J H; Andrews, L (1985): 'Evaluation of a spray nozzle patternator.' Crop Protection, 5. pp $8-11$.

Richardson, B.; W. C. Schou ; M. O. Kimberley, (2000): 'Defining acceptable levels of spray deposit variation from aerial herbicide applications.' ASAE Meeting Paper $00-1054$.

Ringel, R. ; W. A. Taylor and P. G. Andersen (1991): 'Changing spray deposits from horizontal to vertical surfaces at ground level within cereal rows using air assistance.' BCPC Mono 46. pp 297 - 298

Sehsah E.E. (2007) Study effect of forward speed and the spray nozzles types on the spray characteristics of air assistance hydraulic sprayer. M.J.Agric.Eng Vol.24.Nr.1 75-87.

Sehsah, E.E and S. Kleisinger (2007): Low pressure liquid atomizer for biological pest control. Misr Journal of Agric. Eng. Vol. 24.No. 1. 62-74.,

Sehsah E.E. and S. Kleisinger (2009) Study of some parameters affecting spray distribution uniformity pattern. M. J. Agric Eng. Vol. 26.No. (1) .69-92.

Sinfort, C and Herbst, A (1996): 'Evaluation of the quality of spray distribution from boom sprayers in practical conditions.' EPPO Bull 26. pp $27-36$. 


\section{الملخص العربيى \\ الموزع الرآسى لتقييم آلات الرش الهيدروليكية

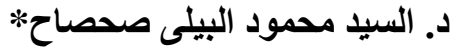

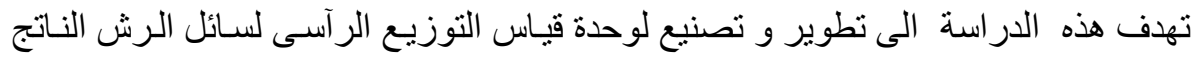

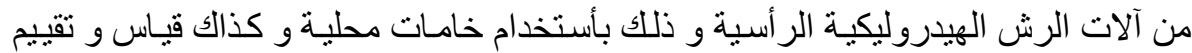

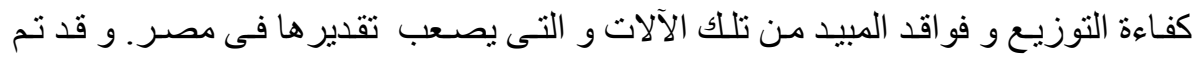

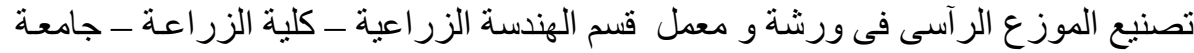

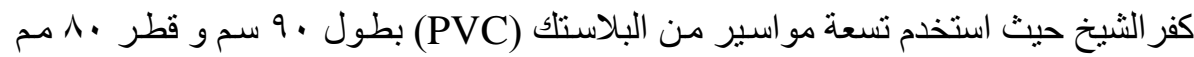

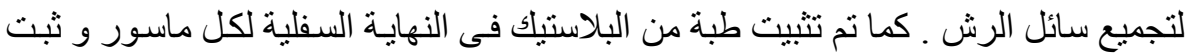

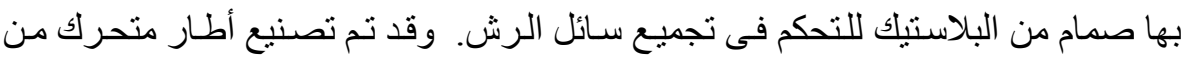

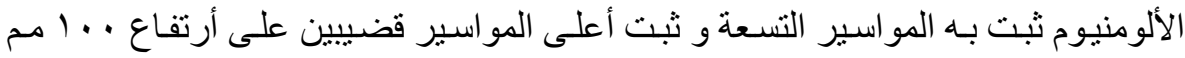

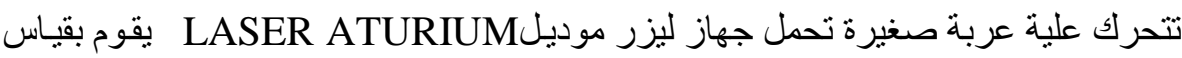

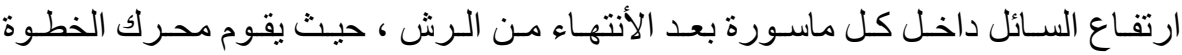

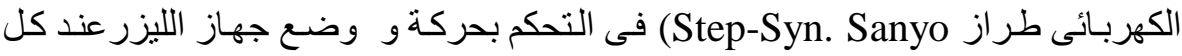

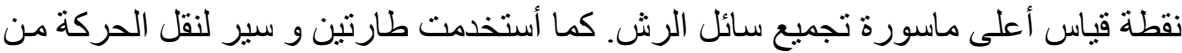

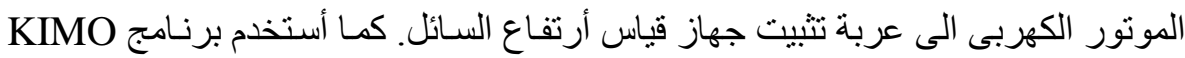

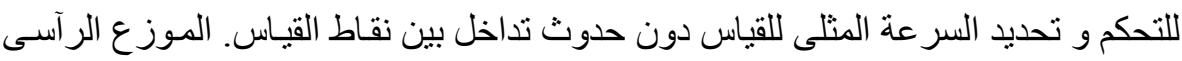

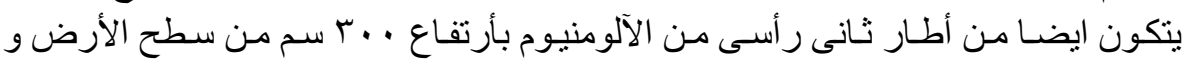

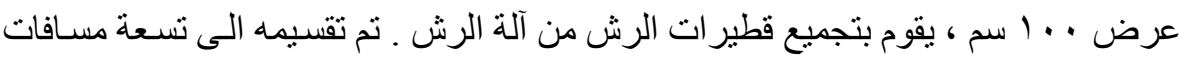

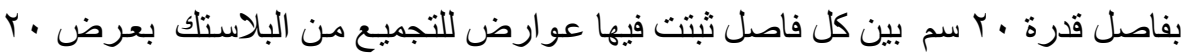

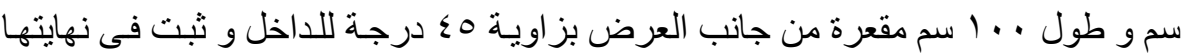

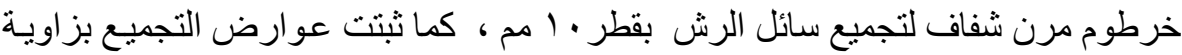

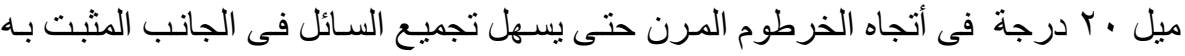

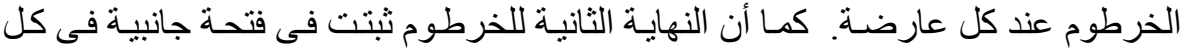

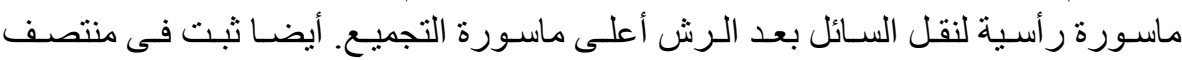

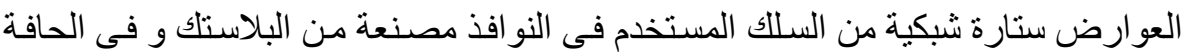
الخلفية للعو ارض ثبت ستارة (Plastic sheet 40 micron ) من البلاستك للحد من من فقد البارة

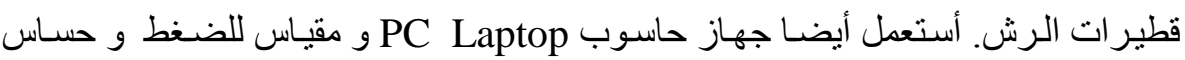

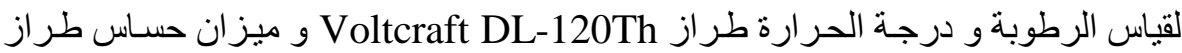

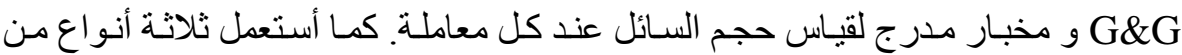

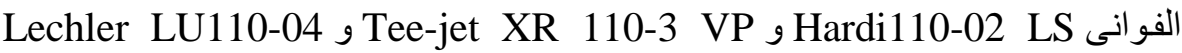
ثبت أثنين من كل نوع منها فى حامل للبانشبير الر آسي كبديل للرشاشـات الهو ائيسة المستعملة فى أشجار الفاكهه.

* أستاذ مساعد - فسم الهندسة الزراعيةـ كلية الزراعة - جامعة كفر الثيخ 
كما تم أجر اء الأختبار ات و المعاملات التالية : دراسـة تأثير ضنغوط التشتيل حيث أستخدم

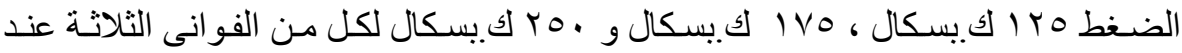

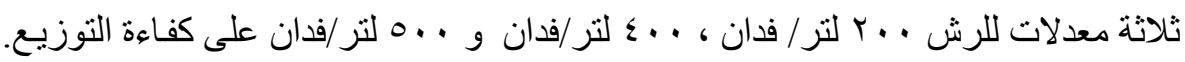

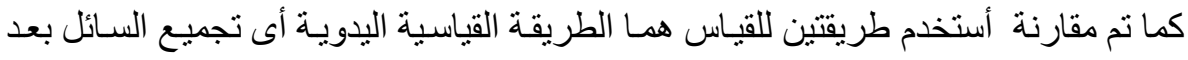

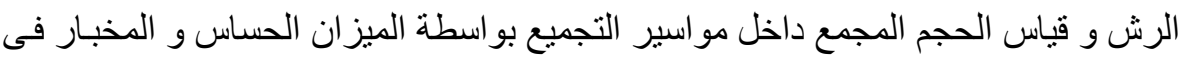

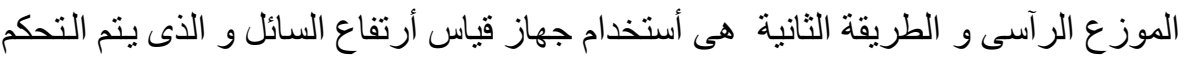

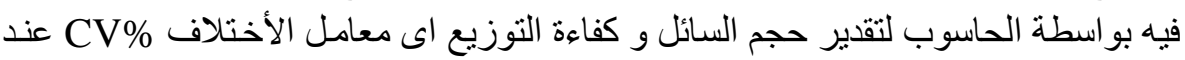
كل معاملة من معاملات التجربة.

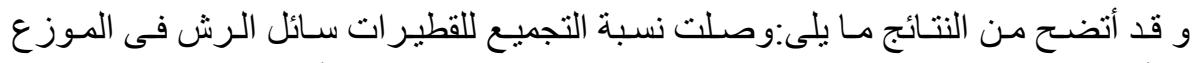

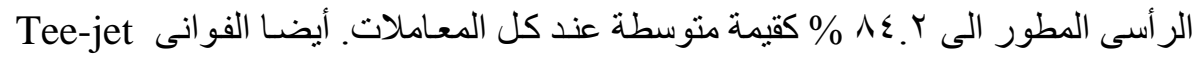

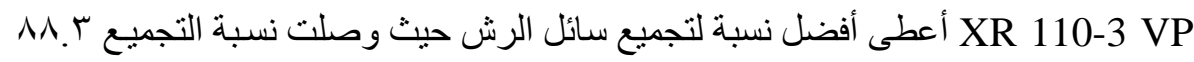

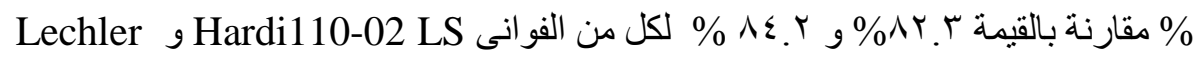

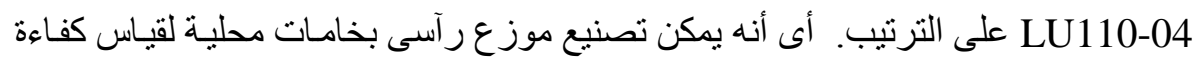

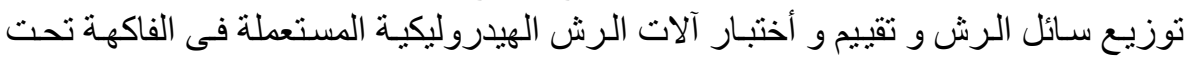

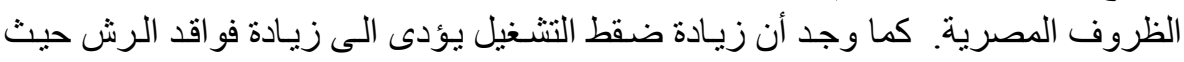

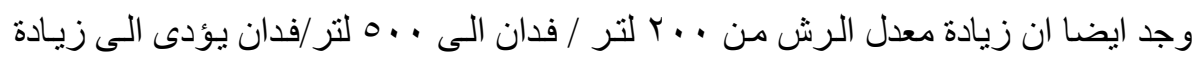

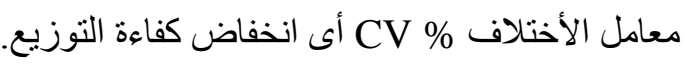

